\title{
A study on physico-chemical properties and uses of coal ash of Barapukuria Coal Fired Thermal Power Plant, Dinajpur, for environmental sustainability
}

\author{
M. Farhad Howladar ${ }^{1} \cdot$ Md. Raisul Islam ${ }^{1}$ \\ ${ }^{1}$ Department of Petroleum and Mining Engineering, Shahjalal University of Science and Technology, Sylhet 3114, Bangladesh
}

Received: 15 October 2015/Revised: 12 January 2016/Accepted: 3 May 2016/Published online: 12 May 2016

(C) Joint Center on Global Change and Earth System Science of the University of Maryland and Beijing Normal University and Springer-Verlag Berlin Heidelberg 2016

\begin{abstract}
The Barapukuria $2 \times 125 \mathrm{MW}$ Coal Fired Thermal Power Plant generates significant quantities of solid by-products which are conventionally known as fly ash. These quantities are about 0.08 million metric tons per year which is currently disposing into two designated ash ponds as a waste material. Nowadays, this ash disposal process with its safe management becomes environmental important issues and major challenges to the industry, environmentalists, scientists and so on. As a consequence, this study principally deals with the assessment of different properties and uses of coal ash for safe environment around the plant area. Thus, the prime objectives of this research are to evaluate the physical, chemical and engineering properties of coal ash for its classification, suitable options of utilizations and safe environment under direct field investigation and laboratory analysis. The results of various analysis implied that physically the color of ash is light gray but varies from gray to dark gray, where the sizes of the particles are in the ranges from $<0.075$ to $0.16 \mathrm{~mm}$ in diameter; accordingly, this ash can be classified as fine sand/silt to clay. The analyzed major and minor chemical properties of coal ash indicate good quality ash. In addition, the major compositions suggest the similar quality while the concentration of $\mathrm{SiO}_{2}(50.61 \%), \mathrm{Al}_{2} \mathrm{O}_{3}$ $(38.55 \%)$ and $\mathrm{Fe}_{2} \mathrm{O}_{3}(3.68 \%)$ are about $90 \%$. The intensity level of major and minor components of this ash is $\mathrm{SiO}_{2}>\mathrm{Al}_{2} \mathrm{O}_{3}>\mathrm{TiO}_{2}>\mathrm{Fe}_{2} \mathrm{O}_{3}>\mathrm{CaO}>\mathrm{P}_{2} \mathrm{O}_{5}>\mathrm{MgO}>$ $\mathrm{K}_{2} \mathrm{O}>\mathrm{SO}_{3}>\mathrm{Mn}_{3} \mathrm{O}_{4}>\mathrm{Na}_{2} \mathrm{O}$ and $\mathrm{Mn}>\mathrm{Zn}>\mathrm{As}>$ $\mathrm{Cu}>\mathrm{Cr}>\mathrm{Pb}>\mathrm{Co}>\mathrm{Cd}$, respectively. In the case of engineering properties, grain size, hydraulic conductivity,
\end{abstract}

M. Farhad Howladar

farhadpme@gmail.com; farhad-pme@sust.edu consistency, compaction, compressive strength and shear strength aspects are presented. The results replicate that effect of addition of coal ash with sand and cement can improve the quality of mixtures specifically increasing the consistency, compressive strength, shear strength and bearing capacity, whereas reducing the hydraulic conductivity of concrete or soil. At the end, a concise discussion has been drawn on the prospective utilizations and management of this ash for present and future environmental sustainability around the area.

Keywords Barapukuria Coal Fired Thermal Power Plant (BTPP) - Coal ash · Coal properties · Utilization · Environment

\section{Introduction}

The Barapukuria Coal Fired Thermal Power Plant (BTPP) is located in Hamidpur union of Parbatipur Upazila, Dinajpur district. It is situated in flat paddy land in the northwestern corner of Bangladesh about $45 \mathrm{~km}$ east of the district headquarters of Dinajpur and $20 \mathrm{~km}$ east from the border of India. According to the Bangladesh topographic sheet no. 78C/14 (scale 1:50,000), the study area lies between the latitudes $25^{\circ} 33^{\prime} 57^{\prime \prime}$ to $25^{\circ} 33^{\prime} 24^{\prime \prime} \mathrm{N}$ and the longitudes $88^{\circ} 56^{\prime} 71^{\prime \prime}$ to $88^{\circ} 56^{\prime} 43^{\prime \prime} \mathrm{E}$. To meet the demand of electricity all over the country, Bangladesh Power Development Board (BPDB) started their commercial operation of $2 \times 125 \mathrm{MW}$ thermal power plant in June 2006 which is the first ever coal-based power plant in Bangladesh. By the development of BTPP (Fig. 1), a new dimension is added to the economy of Bangladesh. From 
Fig. 1 a The location map of the BTPP, Dinajpur,

Bangladesh (CMC 2003); b the birds eye view of BTPP (BPDB 2012)
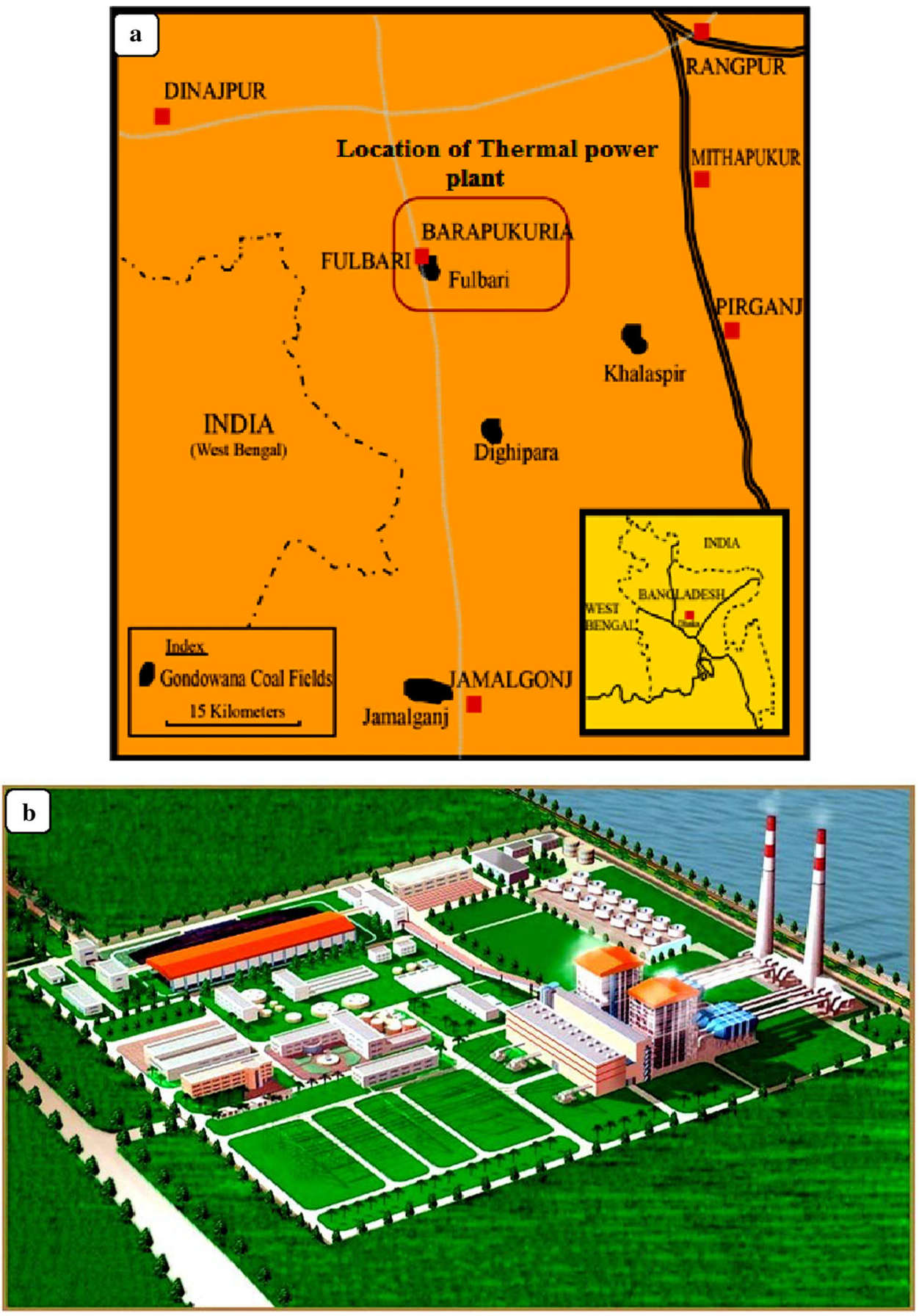

the year 2006, this plant consumed about $70 \%$ coal which is extracting by Barapukuria Coal Mine (BCM) for electrical power generation (BPDB 2012-unpublished). The BTPP has the capacity to consume about 3333 tons of coal per day. From the annual report of BPDB (2012), every year 0.72 million metric tons of coal is consumed, and consequently, 0.08 million metric tons of coal ash is generated from this power plant. These ashes are dumped with water in two ash ponds near the BTPP, where this dumped water is being discharged by an artificial channel to the river Tilai. However, in the present day the amount of coal ash produced from this power plant cannot be ignored because of its direct or indirect impact on environment. Many researchers reported that the coal ash can contaminate the soil, water, air and other components of environment through the mobilization of toxic elements (EPRI 2008; Silva et al. 2009; Howladar 2012; Hashan et al. 2013; Cutruneo et al. 2014; Dias et al. 2014; Garcia et al. 
2013; Howladar et al. 2014; Martinello et al. 2014; Sanchís et al. 2015 and so on). The leaching of heavy or toxic elements from coal ash can cause acute or chronic toxicity in the soil and water environs (Finkelman et al. 1990; Wang et al. 1999; Gutta 1999). The presence of calcium in the ash can limit the release of dissolved arsenic by formation of calcium arsenic precipitates (EPRI 2008). In the case of recent reused scenarios of coal fly ash in different countries of world like Europe, Japan and United States are reused about 40-50\%, $60 \%$ and 20-30\%, respectively (Adriano et al. 1980; Wong and Wong 1989; Chang et al. 1977; Theis and Gardner 1990; Sandhu and Mills 1991; Yoshimoto et al. 2012; ACCA 2014) whereas still Bangladesh is very unfamiliar to reuse the coal ash produced from this thermal plant. Moreover, there are some researches conducted by Howladar (2012, 2015), Howladar and Hasan (2014), Howladar and Karim (2014), Howladar et al. (2014, 2015), Karim and Howladar (2013), Karim et al. (2014), Hashan et al. (2013) and others on engineering geology, water and environment around this thermal plant and coal mine, but no research conducted yet on coal ash, its usages, environmental impacts and management at this site. Thus, the prime objectives of this study are to ascertain the physical, chemical and engineering properties of the coal ash to develop the possible plan on the utilization of disposed coal ash which must be helpful to reduce the disposal problem around the area. Finally, this study describes and recommends the possible sectors of reuse and management of ash for safe and sound environment.

\section{The formation of coal ash in BTPP with its potential environmental hazards}

In the BTPP, coal is burnt through high temperature ranges from 1400 to $1500{ }^{\circ} \mathrm{C}$ with an excess air about $20 \%$ in the furnace. During this process, the coal is crushed into powder-like fine materials which are pumped with compressed air into the boiler. Coal powder is fired to generate heat, which plays the vital role to produce steam to run through the turbine. After burning the coal, the coarse ash or 'bottom ash' are collected from the bottom part of the boiler, whereas the finer particles are collected from the electrostatic precipitators (ESP) unit. These collected particles are conventionally known as fly ash. The processes of generation of coal ash from Barapukuria Thermal Power Plant are shown in Fig. 2. At this plant, the fly ash does not exposed but automatically collected and transported by pneumatic supply line to make slurry and dump them into a large pond called ash pond where it is reserved under the water. The storage of fly ash in ponds further requires large quantities of water (average ash/water ratio is 1:12), involving huge capital and operating costs in setting up and running the mixing, pumping and transportation facilities. Though there are many uses of ash, it is essential to understand the environmental impacts before its utilization. Actually, the health and environmental hazards mainly come from the toxic and radioactive elements of the ash residues. Contaminated leaches from acidic fly ash can pose the highest toxicity problem for aquatic environments (Roy et al. 1984). Coal ash composed of heavy metals like lead $(\mathrm{Pb})$ is of large public concern due to toxicity to animals as well as human beings, especially young children (Manz 1999). Fly ash also consists of considerable amount of organic and inorganic chemical components such as arsenic, cadmium, chromium, lead, mercury, selenium and copper which have adverse effects on living beings and can contaminate the environment as a whole.

\section{Materials and methods}

Coal fly ash is a very fine material produced by the burning of pulverized coal in a thermal power plant carried by the flue gas and collected by the electrostatic precipitator. The research material of this analysis is disposed coal ash which collected from BTTP. Actually, the present research mainly deals with the assessment of physical, chemical and engineering properties by laboratory tests. In the case of understanding the common physical characteristics, the coal ash simply examined by naked eye with hand, whereas the chemical analysis of collected ash samples had been performed in laboratory. Different types of methods were used to determine different parameters of the samples. To analyze the chemical properties of fly ash, primarily the necessary quantity of ash samples was digested with aqua regia. Then the digested samples were analyzed by graphite atomization method and flame atomization method in atomic absorption spectroscopy (AAS-240, Agilent, Australia). Arsenic, chromium, cobalt, copper, cadmium and lead were measured by graphite atomization method. Zinc and manganese were measured by flame atomization method. Atomic absorption spectroscopy (AAS) is a spectroanalytical procedure for the quantitative determination of chemical elements employing the absorption of optical radiation (light) by free atoms in the gaseous state. Graphite furnace atomic absorption spectrometry (GFAAS) [also known as electrothermal atomic absorption spectrometry (ETAAS)] is a type of spectrometry that uses a graphite-coated furnace to vaporize the sample. The evaluation of engineering properties of the samples such as particle sized, compressive strength, direct shear, permeability and consistency has been determined and estimated with the standard testing method in laboratory. Particularly, the particle size has been determined with the ASTM sieves no. 4, 8, 12, 30, 45,100, 200 after ASTM C-136 (2005). The compressive strength has been tested 
Fig. 2 The ways of generating fly ash and bottom ash in the BTPP, Parbatipur, Bangladesh

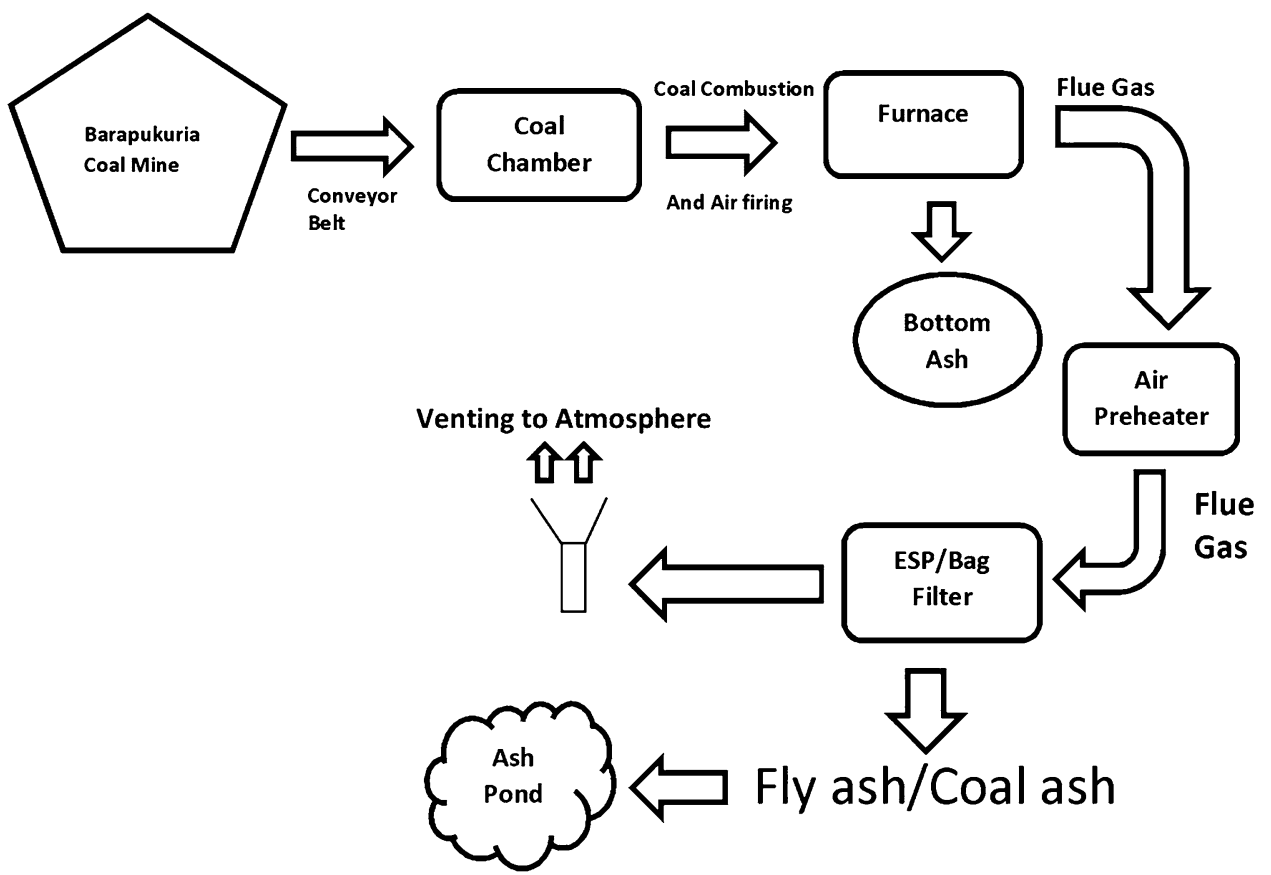

under the ASTM C 109 (2010). In this analysis the total of 48 cubic specimens of $0.05 \mathrm{~m} \times 0.05 \mathrm{~m}$ dimensions were prepared with different proportions for the experiments. The direct shear strength parameters were analyzed using ASTM D 5321 (2003). From the experiments, the shear strength parameters are calculated based on the Mohr-Coulomb strength equation ( $\tau=\mathrm{c}+\sigma \tan \Phi$ ) where $\tau=$ shearing resistance of soil at failure; $C=$ apparent cohesion of soil; $\sigma=$ total normal stress on failure plane; and $\Phi=$ angle of shearing resistance of soil (angle of internal friction). This research determined the permeability through the constant head method and then calculated the permeability, using the equation $K_{\mathrm{T}}=Q L / A$ th, where $K_{\mathrm{T}}=$ the coefficient of permeability $(\mathrm{m} / \mathrm{s}) ; L=$ length of the specimen in centimeter; $Q=$ the volume rate of flow through the fill $\left(\mathrm{m}^{3} / \mathrm{s}\right) ; A=$ the cross-sectional area of the fill $\left(\mathrm{m}^{2}\right)$; and $h=$ the head differential across the fill (m). Finally, the consistency of the coal ash has been specified by the IS:4031 (1988). The results of particle size analysis, compressive strength, shear strength and consistency of ash are shown in Tables 1, 2, 3 and 4, respectively.

\section{Results and discussion}

\subsection{The physical and chemical characteristics of coal ash}

The physical and chemical properties are the most important parameters for understanding the quality of the coal ash. Physically, the fly ash of BTPP is a fine powdery material, with most of its grains that are recognizable by naked eye. The color of fly ash particles is either actually colorless or dark to very dark (Diamond 1985). The color is one of the vital physical properties of fly ash in terms of estimating the lighter or darker substances qualitatively. Usually, it is suggested that the lighter color indicates the presence of high calcium oxide, whereas darker colors suggest high organic materials. Studied ash is mostly light gray but ranges from gray to dark gray color where most of the particles sizes are silt to clay which replicates the calcium oxide-dominated coal ash produced from BTPP. The chemical constituents of fly ash of this analysis are shown in Table 5. The major and minor constituents of coal ash are $\mathrm{SiO}_{2}, \mathrm{Fe}_{2} \mathrm{O}_{3}, \mathrm{Al}_{2} \mathrm{O}_{3}$ and $\mathrm{CaO}, \mathrm{K}_{2} \mathrm{O}, \mathrm{Na}_{2} \mathrm{O}$, $\mathrm{MgO}, \mathrm{TiO}_{2}, \mathrm{P}_{2} \mathrm{O}_{5}$ and $\mathrm{SO}_{3}$, respectively (Selvig and Gibson 1956; Abernethy et al. 1969). In bituminous coal, three major components $\left(\mathrm{SiO}_{2}, \mathrm{Fe}_{2} \mathrm{O}_{3}\right.$ and $\left.\mathrm{Al}_{2} \mathrm{O}_{3}\right)$ account for about $90 \%$ of the total components, whereas lignite and sub-bituminous coal ashes have relatively high percentages of $\mathrm{CaO}$ and $\mathrm{MgO}$ and correspondingly have large amounts of sulfur (Abernethy et al. 1969; Nath 1997).

It is well known that generally there are two types of fly ash such as class $\mathrm{C}$ and class $\mathrm{F}$, where class $\mathrm{C}$ fly ash is normally generated from burning of sub-bituminous or lignite coals, and on the other side, burning bituminous or anthracite coals produce class $\mathrm{F}$ fly ash. The class $\mathrm{F}$ must contain about seventy percent of $\left(\mathrm{SiO}_{2}+\mathrm{Al}_{2} \mathrm{O}_{3}+\mathrm{Fe}_{2} \mathrm{O}_{3}\right)$, whereas type $\mathrm{C}$ contained minimum of $50 \%$ of $\left(\mathrm{SiO}_{2}+\mathrm{Al}_{2} \mathrm{O}_{3}+\mathrm{Fe}_{2} \mathrm{O}_{3}\right)$ (Collins 1988, Fig. 3). From the above discussion it can be noted here that the summation of $\mathrm{SiO}_{2}, \mathrm{Al}_{2} \mathrm{O}_{3}$ and $\mathrm{Fe}_{2} \mathrm{O}_{3}$ is more than $70 \%$ which suggests that the class F-type fly ash produced from this plant. From the major chemistry of this 
Table 1 The average results of particle analysis of sand

\begin{tabular}{llllll}
\hline Sieve number & Sieve opening $(\mathrm{mm})$ & Weight $(\mathrm{gm})$ & Materials retained $(\%)$ & Cumulative retained $(\%)$ & Finer $(\%)$ \\
\hline 16 & 1.18 & 3.5 & 0.7 & 0.7 & 99.3 \\
18 & 1 & 1.5 & 0.3 & 1.0 & 9.5 \\
20 & 0.85 & 2.5 & 0.5 & 5.1 & 98.5 \\
30 & 0.6 & 18.0 & 3.6 & 25.1 & 94.9 \\
40 & 0.425 & 100 & 20.0 & 45.0 & 74.9 \\
45 & 0.355 & 99.5 & 19.9 & 97.6 & 55.0 \\
120 & 0.125 & 263 & 52.6 & 99.2 & 0.8 \\
170 & 0.09 & 8.1 & 1.62 & 99.5 & 0.5 \\
200 & 0.075 & 1.5 & 0.3 & 100 & 0 \\
$200+$ & $<0.075$ & 2.5 & 0.5 & \\
\hline
\end{tabular}

Table 2 The average results of particle analysis of fly ash

\begin{tabular}{|c|c|c|c|c|c|}
\hline Sieve number & Sieve opening $(\mathrm{mm})$ & Weight retained $(\mathrm{gm})$ & Materials retained $(\%)$ & Cumulative retained (\%) & Finer $(\%)$ \\
\hline 16 & 1.18 & 0 & 0 & 0 & 100 \\
\hline 18 & 1 & 0 & 0 & 0 & 100 \\
\hline 20 & 0.85 & 0.01 & 0.05 & 0.05 & 99.95 \\
\hline 30 & 0.6 & 0.16 & 0.08 & 0.13 & 99.87 \\
\hline 40 & 0.425 & 0.23 & 0.12 & 0.25 & 99.75 \\
\hline 100 & 0.16 & 142.56 & 71.28 & 71.53 & 28.47 \\
\hline 120 & 0.125 & 36.63 & 18.32 & 89.85 & 10.15 \\
\hline 170 & 0.09 & 12.56 & 6.28 & 96.13 & 3.87 \\
\hline 300 & 0.075 & 2.04 & 1.02 & 97.15 & 2.85 \\
\hline $300+$ & $<0.075$ & 5.81 & 2.91 & 100 & 0 \\
\hline
\end{tabular}

plant fly ash, it is observed that the percentage of $\mathrm{SiO}_{2}$ and $\mathrm{Fe}_{2} \mathrm{O}_{3}$ is about $90 \%$ (Fig. 4). If we compare this ash with other countries, consequently the category of Bangladesh fly ash will be more understandable. The average percentage of major chemical composition of analyzed fly ashes is $\mathrm{SiO}_{2}=54.4 ; \quad \mathrm{Al}_{2} \mathrm{O}_{3}=35.6 ; \quad \mathrm{TiO}_{2}=3.2 ; \quad \mathrm{Fe}_{2} \mathrm{O}_{3}=2.9 ;$ $\mathrm{CaO}=0.56 ; \quad \mathrm{P}_{2} \mathrm{O}_{5}=0.46 ; \quad \mathrm{MgO}=0.18 ; \quad \mathrm{K}_{2} \mathrm{O}=0.66 ;$ $\mathrm{SO}_{3}=0.13 ; \mathrm{Mn}_{3} \mathrm{O}_{4}=0.11$; and $\mathrm{Na}_{2} \mathrm{O}=0.06 \%$ as shown in Fig. 5 along with corresponding data for different countries' fly ashes. From these scenarios, it is obvious that fly ash of the current analysis is more siliceous as compared to American, German and British coal fly ash. On the other hand, the average minor or trace compositions of the studied ash exhibit the arsenic (As) $52 \mathrm{ppm}$; chromium (Cr) $15 \mathrm{ppm}$; cobalt (Co) 5 ppm; copper (Cu) 16 ppm; zinc (Zn) 135 ppm; manganese $(\mathrm{Mn}) 136 \mathrm{ppm}$; cadmium $(\mathrm{Cd})$ below detection level; and lead $(\mathrm{Pb}) 6$ ppm which shows approximately similar concentration with EPRI (2008).

\subsection{Engineering properties of fly ash}

In this research, the particle size gradation, unconfined compressive strength, compaction, hydraulic conductivity, direct shear strength and consistency level have been estimated to understand the engineering properties of coal ash. The particle size gradation characteristics typically meant the separation of an ash/soil particle into its different size fractions. According to Karim (1997), fly ash is a fine, powder-like material in which grain sizes range from 0.6 to $0.001 \mathrm{~mm}$ and span the range from fine sands and silt to large clay particles. However, Fig. 6a, b represents the sieve analysis of fly ash and sand samples of the study which shows that most of the particles size is fine sand and the diameter ranges from 0.09 to $0.6 \mathrm{~mm}$. On the other hand, most of the particles size of fly ash sample is in the range of $<0.075-0.16 \mathrm{~mm}$ in diameter. Consequently, the studied fly ash can be classified as fine sand/silt to clay.

The compaction is the process of densification of a material by appealing loads for increasing the dry density of material. In the case of compaction characteristics (Fig. 7), this analysis observed that the highest density of coal fly ash is $2.26 \times 10^{3} \mathrm{~kg} / \mathrm{m}^{3}$ at $12 \%$ water content. The mixture ratios are 1:0:0, 1:0:1.5, 1:1:6.34, 1:1:5.14, $0.8: 0.2: 2.5$, where the cement and ash content is varied as wt $\%$ like 100, 40, 24, 28, $28.6 \%$ with different curing ages such as 7, 14 and 28 days (Fig. 7), respectively. The 
Table 3 The unconfined compressive strength of cubic samples of different mixtures of cement, coal fly ash and sand

\begin{tabular}{|c|c|c|c|c|}
\hline $\begin{array}{l}\text { Mix ratios } \\
\text { (cement:ash:sand) }\end{array}$ & $\begin{array}{l}\text { Curing duration } \\
\text { (days) }\end{array}$ & $\begin{array}{l}\text { Load on } \\
\text { specimens }(\mathrm{KN})\end{array}$ & $\begin{array}{l}\text { Compressive } \\
\text { strength (MPa) }\end{array}$ & $\begin{array}{l}\text { Average compressive } \\
\text { strength (MPa) }\end{array}$ \\
\hline \multirow[t]{9}{*}{$1: 0: 1.5$} & 7 & 55 & 22 & 19.3 \\
\hline & & 50 & 20 & \\
\hline & & 40 & 16 & \\
\hline & 14 & 65 & 26 & 24 \\
\hline & & 65 & 26 & \\
\hline & & 50 & 20 & \\
\hline & 28 & 90 & 36 & 36 \\
\hline & & 90 & 36 & \\
\hline & & 90 & 36 & \\
\hline \multirow[t]{9}{*}{ 1:0:0 } & 7 & 45 & 18 & 19.33 \\
\hline & & 50 & 20 & \\
\hline & & 50 & 20 & \\
\hline & 14 & 53 & 21.2 & 21.37 \\
\hline & & 54 & 21.6 & \\
\hline & & 53.3 & 21.32 & \\
\hline & 28 & 80 & 32 & 32 \\
\hline & & 80 & 32 & \\
\hline & & 80 & 32 & \\
\hline \multirow[t]{9}{*}{$1: 1: 6.34$} & 7 & 2 & 0.8 & 0.86 \\
\hline & & 2 & 0.8 & \\
\hline & & 2.5 & 1.0 & \\
\hline & 14 & 4 & 1.6 & 1.67 \\
\hline & & 4 & 1.6 & \\
\hline & & 4.5 & 1.8 & \\
\hline & 28 & 6 & 2.4 & 2.47 \\
\hline & & 6 & 2.4 & \\
\hline & & 6.5 & 2.6 & \\
\hline \multirow[t]{9}{*}{$1: 1: 5.14$} & 7 & 3.5 & 1.4 & 1.27 \\
\hline & & 3 & 1.2 & \\
\hline & & 3 & 1.2 & \\
\hline & 14 & 8 & 3.2 & 3.4 \\
\hline & & 9 & 3.6 & \\
\hline & & 8.5 & 3.4 & \\
\hline & 28 & 12 & 4.8 & 5 \\
\hline & & 13 & 5.2 & \\
\hline & & 12.5 & 5 & \\
\hline \multirow[t]{9}{*}{$0.8: 0.2: 2.5$} & 7 & 7 & 2.8 & 2.93 \\
\hline & & 7.5 & 3 & \\
\hline & & 7.5 & 3 & \\
\hline & 14 & 10 & 4 & 4.2 \\
\hline & & 10.5 & 4.2 & \\
\hline & & 11 & 4.4 & \\
\hline & 28 & 15.5 & 6.2 & 6.07 \\
\hline & & 15 & 6.0 & \\
\hline & & 15 & 6.0 & \\
\hline
\end{tabular}


Table 4 Consistency test results of coal fly ash with Portland cement

\begin{tabular}{|c|c|c|c|c|c|}
\hline Mixture proportion & Trial no. & Weight of fly ash (gm) & Water (cc) & Water \% & Needle penetration $(\mathrm{mm})$ \\
\hline \multirow[t]{5}{*}{ Fly ash:cement $=1: 0$} & 1 & 200 & 120 & 60 & 3 \\
\hline & 2 & 200 & 132 & 66 & 37 \\
\hline & 3 & 200 & 128 & 64 & 26 \\
\hline & 4 & 200 & 126 & 63 & 12 \\
\hline & 5 & 200 & 124 & 62 & 10 \\
\hline \multirow[t]{5}{*}{ Fly ash:cement $=1: 2$} & 1 & 200 & 120 & 50 & 39 \\
\hline & 2 & 200 & 132 & 49 & 26 \\
\hline & 3 & 200 & 128 & 45 & 17 \\
\hline & 4 & 200 & 126 & 44 & 11 \\
\hline & 5 & 200 & 124 & 43 & 10 \\
\hline \multirow[t]{5}{*}{ Fly ash:cement $=1: 3$} & 1 & 200 & 80 & 40 & 34 \\
\hline & 2 & 200 & 60 & 30 & 2 \\
\hline & 3 & 200 & 70 & 35 & 17 \\
\hline & 4 & 200 & 64 & 32 & 12 \\
\hline & 5 & 200 & 66 & 33 & 10 \\
\hline
\end{tabular}

Table 5 The major chemical constituents of coal ash (Wardell 1991)

\begin{tabular}{lccccccccccc}
\hline Sample no. & \multicolumn{1}{l}{ Parameters $(\%)$} & & & & & & & & & \\
\cline { 2 - 11 } & $\mathrm{SiO}_{2}$ & $\mathrm{SO}_{3}$ & $\mathrm{P}_{2} \mathrm{O}_{5}$ & $\mathrm{MgO}$ & $\mathrm{Al}_{2} \mathrm{O}_{3}$ & $\mathrm{Fe}_{2} \mathrm{O}_{3}$ & $\mathrm{TiO}_{2}$ & $\mathrm{Mn}_{3} \mathrm{O}_{4}$ & $\mathrm{CaO}$ & $\mathrm{K}_{2} \mathrm{O}$ & $\mathrm{Na}_{2} \mathrm{O}$ \\
\hline 1 & 40.22 & 0.65 & 0.27 & 0.300 & 31.88 & 17.24 & 4.51 & 0.50 & 1.62 & 0.68 & 0.081 \\
2 & 39.05 & 0.61 & 0.52 & 0.300 & 33.21 & 10.45 & 2.66 & 0.31 & 1.37 & 0.61 & 0.067 \\
3 & 44.99 & 0.07 & 0.39 & 0.104 & 39.55 & 1.54 & 3.43 & 0.09 & 0.19 & 0.41 & 0.041 \\
4 & 47.15 & 0.03 & 0.49 & 0.130 & 39.18 & 1.86 & 3.54 & 0.14 & 0.16 & 0.63 & 0.051 \\
5 & 55.56 & 0.01 & 0.32 & 0.089 & 31.94 & 1.16 & 3.77 & 0.14 & 0.02 & 0.47 & 0.073 \\
6 & 47.40 & 0.04 & 0.58 & 0.111 & 39.21 & 1.91 & 3.78 & 0.08 & 0.05 & 0.57 & 0.042 \\
7 & 49.86 & 0.04 & 0.35 & 0.112 & 37.38 & 1.13 & 3.18 & 0.10 & 0.09 & 0.61 & 0.041 \\
8 & 56.39 & 0.07 & 0.100 & 0.164 & 38.04 & 3.27 & 2.93 & 0.10 & 0.41 & 0.63 & 0.096 \\
9 & 50.07 & 0.07 & 0.501 & 0.129 & 41.71 & 5.49 & 3.15 & 0.13 & 0.50 & 0.74 & 0.040 \\
10 & 51.70 & 0.02 & 0.312 & 0.144 & 45.87 & 1.29 & 3.85 & 0.05 & 0.45 & 0.60 & 0.033 \\
11 & 51.59 & 0.04 & 0.423 & 0.182 & 44.18 & 1.73 & 3.40 & 0.06 & 0.50 & 0.81 & 0.100 \\
12 & 49.56 & 0.01 & 0.417 & 0.139 & 44.87 & 1.55 & 3.26 & 0.06 & 0.45 & 0.75 & 0.096 \\
13 & 58.42 & 0.02 & 0.376 & 0.138 & 37.56 & 1.68 & 3.72 & 0.07 & 0.39 & 0.70 & 0.097 \\
14 & 58.67 & 0.01 & 0.370 & 0.106 & 35.28 & 4.00 & 3.60 & 0.10 & 0.39 & 0.75 & 0.091 \\
15 & 58.50 & 0.01 & 0.164 & 0.145 & 38.40 & 0.84 & 3.58 & 0.05 & 0.36 & 0.85 & 0.094 \\
Maximum & 58.67 & 0.65 & 0.52 & 0.300 & 45.87 & 17.24 & 4.51 & 0.50 & 1.62 & 0.85 & 0.100 \\
Minimum & 39.05 & 0.01 & 0.100 & 0.089 & 31.88 & 0.84 & 2.66 & 0.05 & 0.02 & 0.47 & 0.041 \\
Average & 50.608 & 0.113 & 0.372 & 0.156 & 38.55 & 3.676 & 3.491 & 0.132 & 0.463 & 0.654 & 0.069 \\
SD & 6.243 & 0.244 & 0.135 & 0.072 & 4.599 & 5.512 & 0.494 & 0.148 & 0.524 & 0.125 & 0.026 \\
\hline & & & & & & & & & & & \\
& & & & & & & & & & &
\end{tabular}

compressive strength analysis reflected that strength is increased with increasing ash and cement content (Table 3) with the curing duration. The shear strength is the basic characteristic that determines the ability of soils to resist loading without failing (Rodriguez et al. 1988). During the shear test, this study determined two shear strength components as cohesion and friction angle. Shear test were conducted on different samples where the coal ash portion increases gradually as 25, 50, 75 and $100 \%$. The results show that the cohesion increases $48-98.67 \mathrm{kPa}$, whereas the friction angle decreases from $24.67^{\circ}$ to $21.70^{\circ}$ as shown in Fig. 8a-d. The hydraulic conductivity of a soil is dependent on the nature of the void system. Coal ash itself is a fine powdery material which has high porosity but 


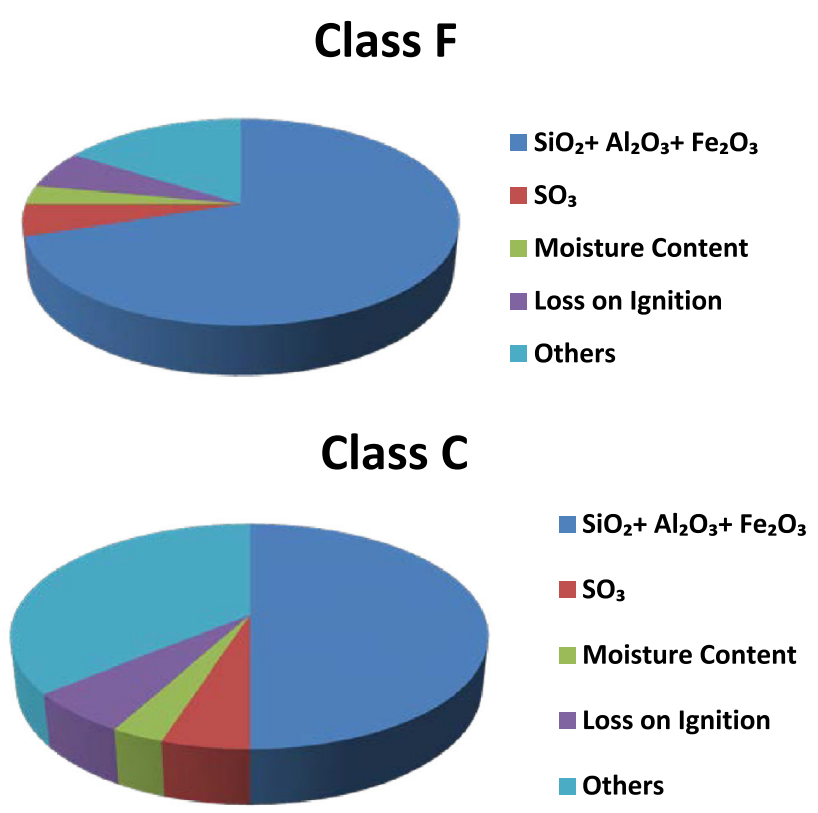

Fig. 3 The classification of fly ash F and C (after ASTM C 618)

negligible permeability. The permeability analysis of this study shows that average permeability is $1.43 \times 10^{-3} \mathrm{~cm} / \mathrm{s}$ which almost matched with permeability values of coal ash analyzed by Martin et al. (1990), Goodwin (1988) and Turgeon (1988). The consistency of coal fly ash is another important engineering property which is measured by the Vicat apparatus using a 10-mm-diameter plunger. The results show higher consistency $62 \%$ in the case of $100 \%$ fly ash, and other cases such as $25 \%$ fly ash $75 \%$ cement and $33.3 \%$ fly ash $66.6 \%$ cement mixtures reflect 33 and $43 \%$ consistency, respectively, which shows the close similarity with the usual consistency range of fly ash between 26 and $33 \%$ as shown in Table 4 .

\subsection{The disposal of fly ash and the present state of environment around the study area}

The physical and chemical properties of coal ash are generally responsible for the potential environmental hazards. In reality, fly ash has a noticeable negative impact on soil, water, air and so on of environment for its compositional variation. Currently, the coal ashes of the studied plants are being dumped in ash ponds near the BTPP (Fig. 9) which are covering the surface soil as well as the root of the plants (Fig. 10) as a result of losing the soil fertility, characteristics, biodiversity and yield for cultivation. In addition, the pozzolanic nature of fly ash may help to harden the soil which directly hampers to grow the plant (Haas and Macak 1985). The ash also affects the permeability of soil which helps to slow down water movement within the soil pores. After Howladar et al. (2015), nitrogen deficiency and phosphorus deficiency were strongly noticed in soil, whereas iron and manganese concentrations show comparatively higher amount in the studied areas which indicates that the fine-grained fly ash content probably reduced the porous and permeable characteristics of soil; consequently, nitrogen and phosphorus are unable to pass into the successive soil layers. In the case of water bodies around the plant area, the contamination of both
Fig. 4 The major chemical compositions of coal ash (Wardell 1991)

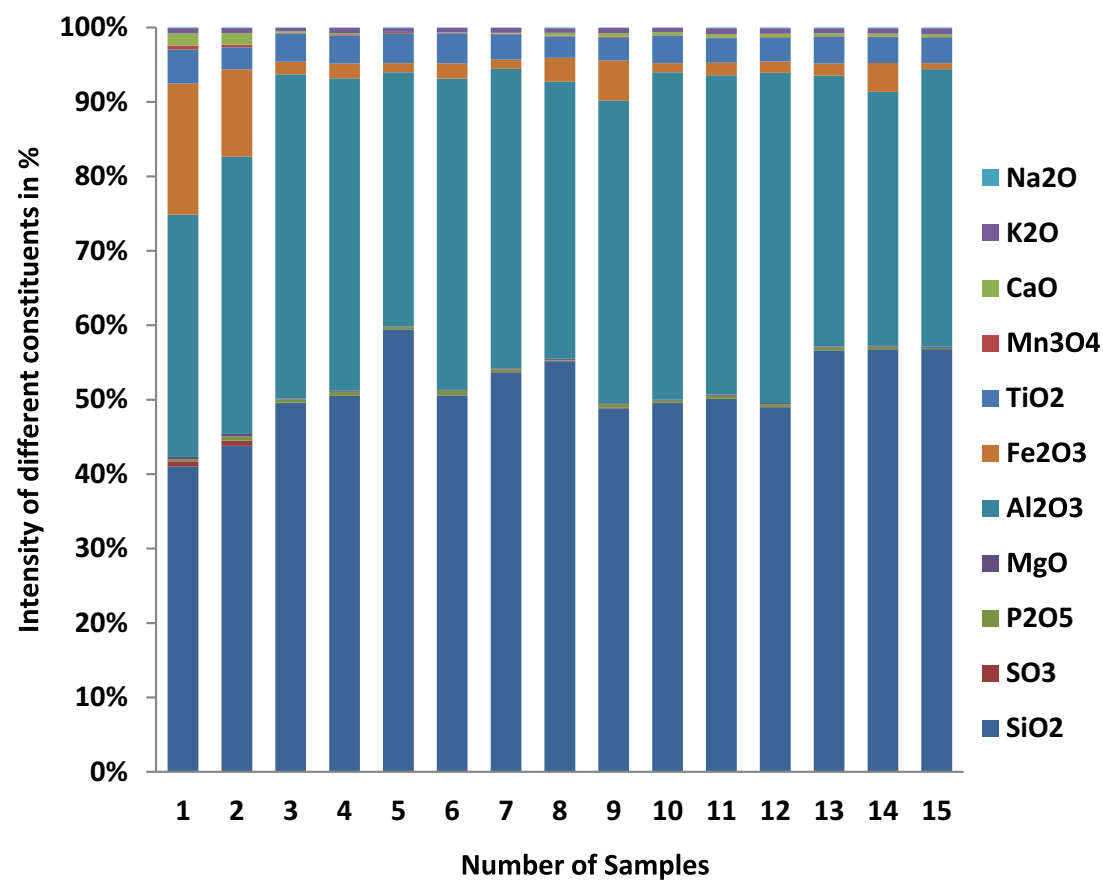


Fig. 5 Comparison between the chemical compositions of studied fly ash with other countries' coal fly ash

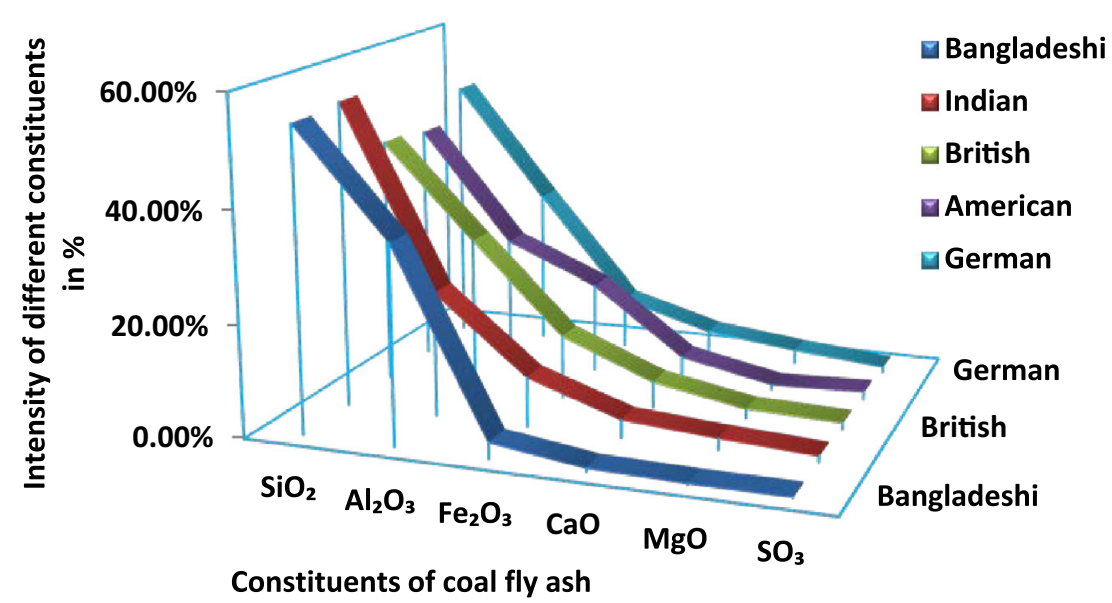

(a)

characteristics according to ASTM C-33. a consisted of fly ash and $\mathbf{b}$ consisted of sand sample

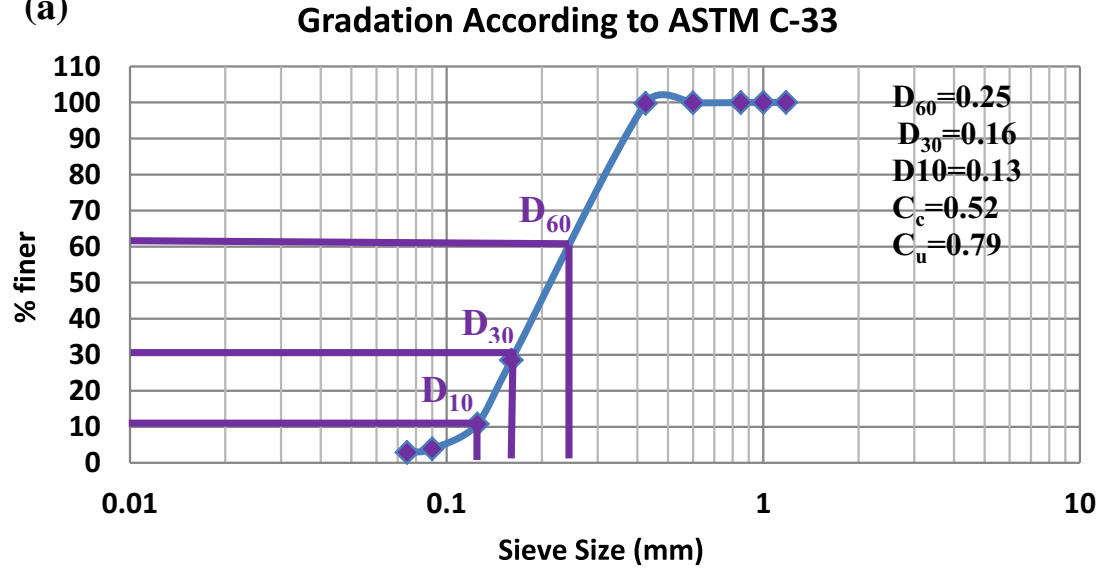

(b) Gradation According to ASTM C-33

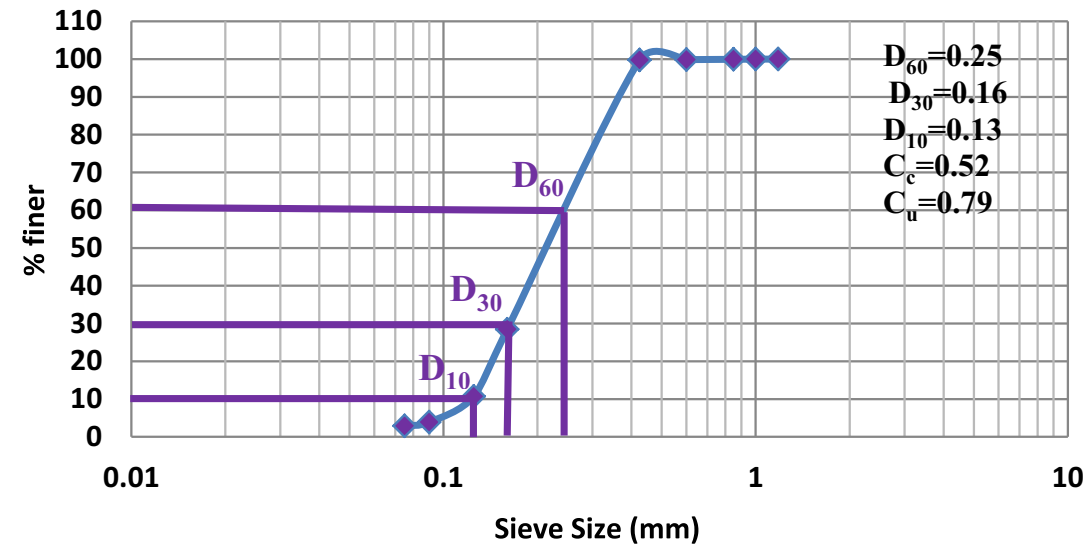

groundwater and nearby streams may be for now and long periods of time. Presently, the polluted blackish water in the river 'Tilai' was observed at the connecting point of the discharge channel with its nearby ponds (Fig. 11). The water quality analysis by Howladar (2012) and Howladar et al. (2014) reported that the concentration of $\mathrm{As}$ and $\mathrm{Cd}$ is slightly higher in the surface water bodies in the areas which might be due to this fly ash, while it consists of higher cadmium and arsenic concentration which are much hazardous for health and environment. It is well known that long-term intake of As in drinking water is much risky for health, while it can cause the internal cancers and other dieses. In the field, it has been seen that the ash pond is getting dried day by day because of discharging the large 


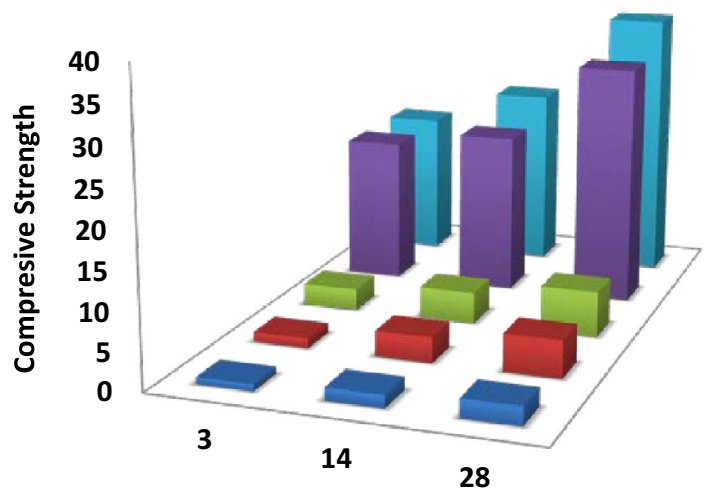

Curing Duration

Fig. 7 Compressive strength of different proportions sample against curing duration

amount of fly ash. As a result, the fly ash layer is getting thicker, mixing with air and pollutes the air environment. Normally, during combustion, the finer components of coal ash react with air and consequently generate different toxic substances such as $\mathrm{CO}_{2}, \mathrm{SO}_{2}$ and $\mathrm{NO}_{2}$ which is readily taken up by living beings so poses a possibility of rising environmental contamination with health risk around this power plant for present and future.

\subsection{The utilization of coal fly ash and the management of environment}

The major utilization of fly ash is as an ingredient in concrete production. In fact, EPRI (2008) and Openshaw (1992) illustrated in detail regarding the various options of the utilization of coal fly ash with its associated environmental impacts. However, Fig. 12 (ACAA survey 2007; EPRI 2008) shows the different amounts of fly ash used in various applications. Usmen et al. (1988) reported on research which evaluated the feasibility of using stabilized fly ash as a low permeable material. Torrey (1978), Chu et al. (1991) and Roy et al. (1984) suggest bricks as a possible option of using coal fly ash. In reality, fly ash can be used in different sectors based on its physical, chemical and engineering properties. In the case of cementing materials, coal ash can bind solid particles, e.g., gravel, sand and aggregate, within a compact structure (Alp et al. 2009; Neville 1995; Yoshimoto et al. 2012; ACCA 2014). Portland cements are frequently characterized by their physical properties. In the present study, Fig. 6 represents the sieve analysis of fly ash sample which implied that most of the particles size is in the range from $<0.075$ to $0.16 \mathrm{~mm}$. The effective grain size of fly ash, $D_{10}, 0.13 \mathrm{~mm}$ and uniformity coefficient $C_{\mathrm{u}}$ and coefficient of curvature $C_{\mathrm{c}}$ is 0.79 and 0.52 , respectively. The consistency of fly ash is $62 \%$. For any cement or natural pozzolan required consistency limit is 25-33\% which suggests that this fly ash can be used as a

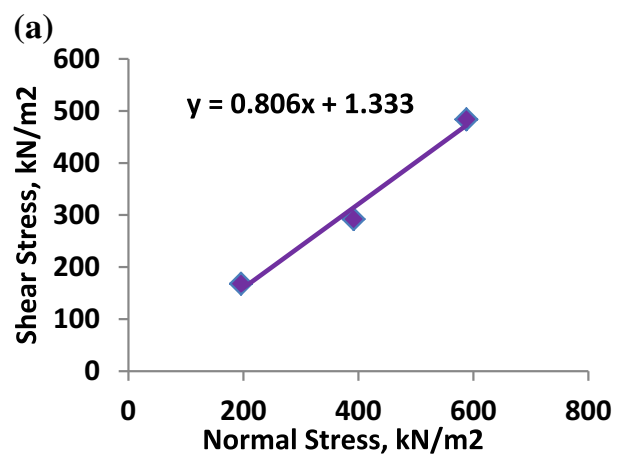

(b)

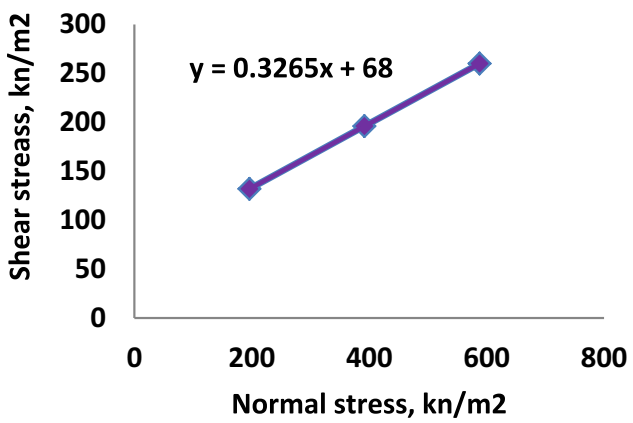

(c)
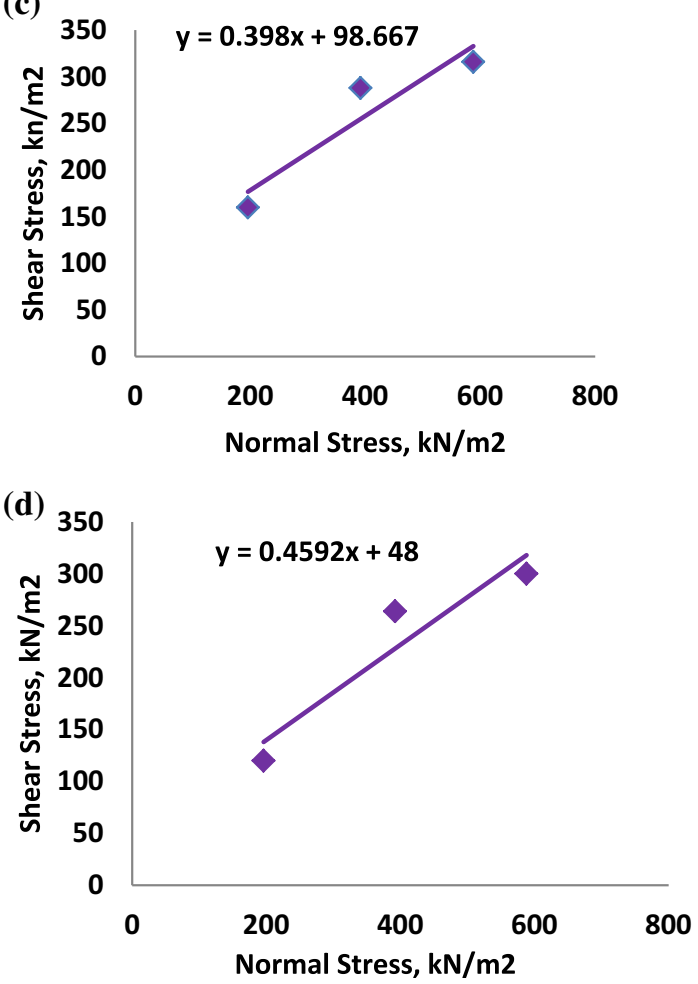

Fig. 8 Shear stress vs. normal stress for a $25 \%$; b $50 \%$; c $75 \%$, and d $100 \%$ fly ash, respectively

mixture material with natural cement. The compressive strength for only fly ash is about zero which is thoroughly unable to bind cube or cylindrical mold, whereas if the fly ash mixed with cement in different ratios, the compressive strength increases with increasing cement content with 

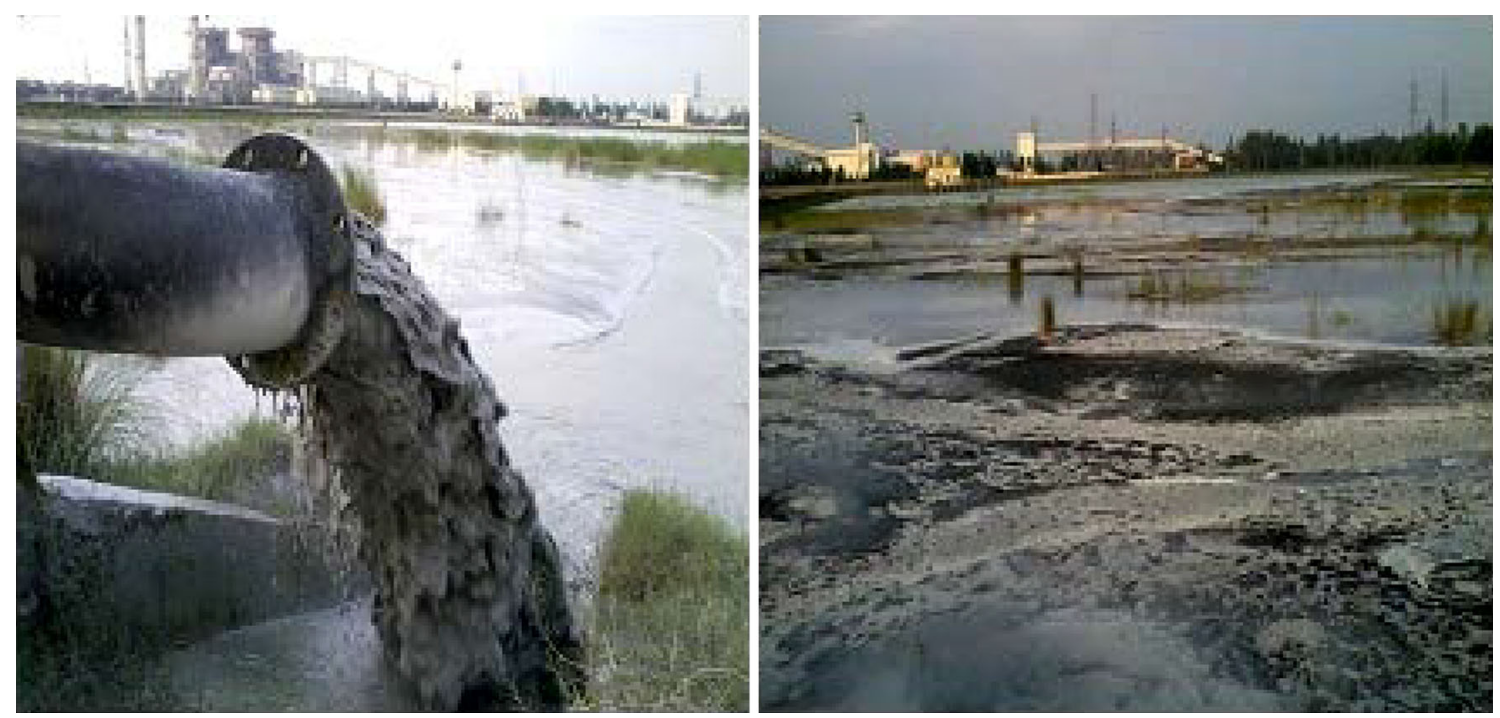

Fig. 9 Fly ash is discharging in an ash pond thoroughly open to the surrounding environment
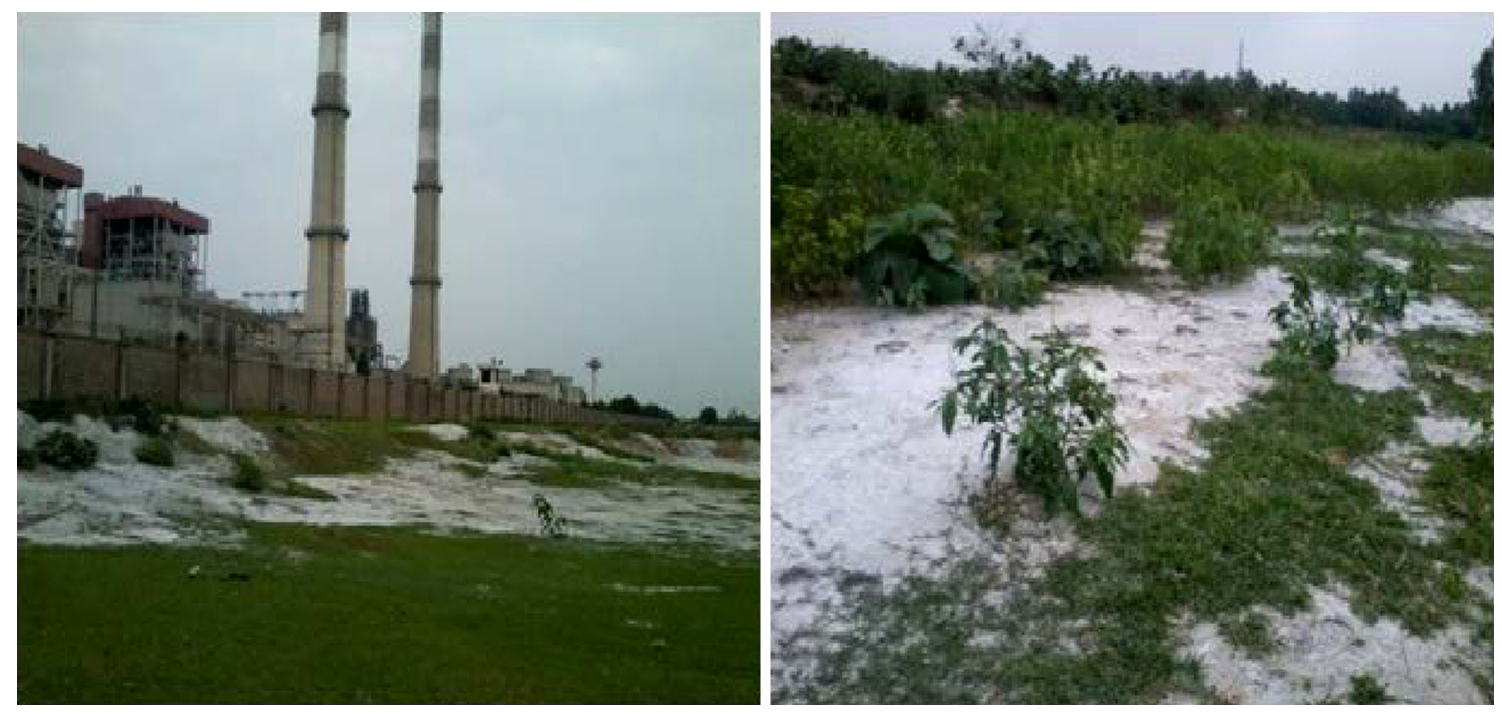

Fig. 10 Fly ash covered the soil and root of the plants as well as it is mixing with the air

curing duration. These results indicate that the mixing of coal fly ash with cement can increase the strength of concrete with time. Thus, it is important to mention here that use of coal fly ash with cement in the case of concrete industry can achieve long-term strength and stable the structures. In other cases, coal ash can be used as an alternative of sand and soil improvement. The comparative grain size analysis of fly ash and sand is shown in Fig. 6a, b. From these figures, it is cleared that coal fly ash consists of about $97.09 \%$ medium sand and rest $2.91 \%$ is silt which is very close to fine sand characteristics proposed by the American Association of State Highway and Transportation Officials, suggesting fly ash can be utilized as the alternative of natural sand. In fact, the role of fly ash to change some soil properties such as the reduction of bulk density, moduli of rupture, increased water holding capacities, and lower the hydraulic conductivity consequently improves the soil quality as a whole (El-Mogazi et al. 1988; Chang et al. 1977; Cheremisinoff 1988). Hence, considering the grain size of ash with its role, this study implies that it can be utilized as the alternative of sand as well as the improvement of soil properties for engineering purposes. The other important use of coal ash is as materials for structural fills and embankments (Ahmed 1991; Ferguson and Levorson 1999). From the present analysis, it has been observed that the compressive strength, direct shear strength, cohesion and angle of internal friction of fly ash show higher values than sand and soil which imply that the use of ash can enhance the stability as well as the longevity of fill materials for all kinds of structures. Moreover, the utilization of ash in 

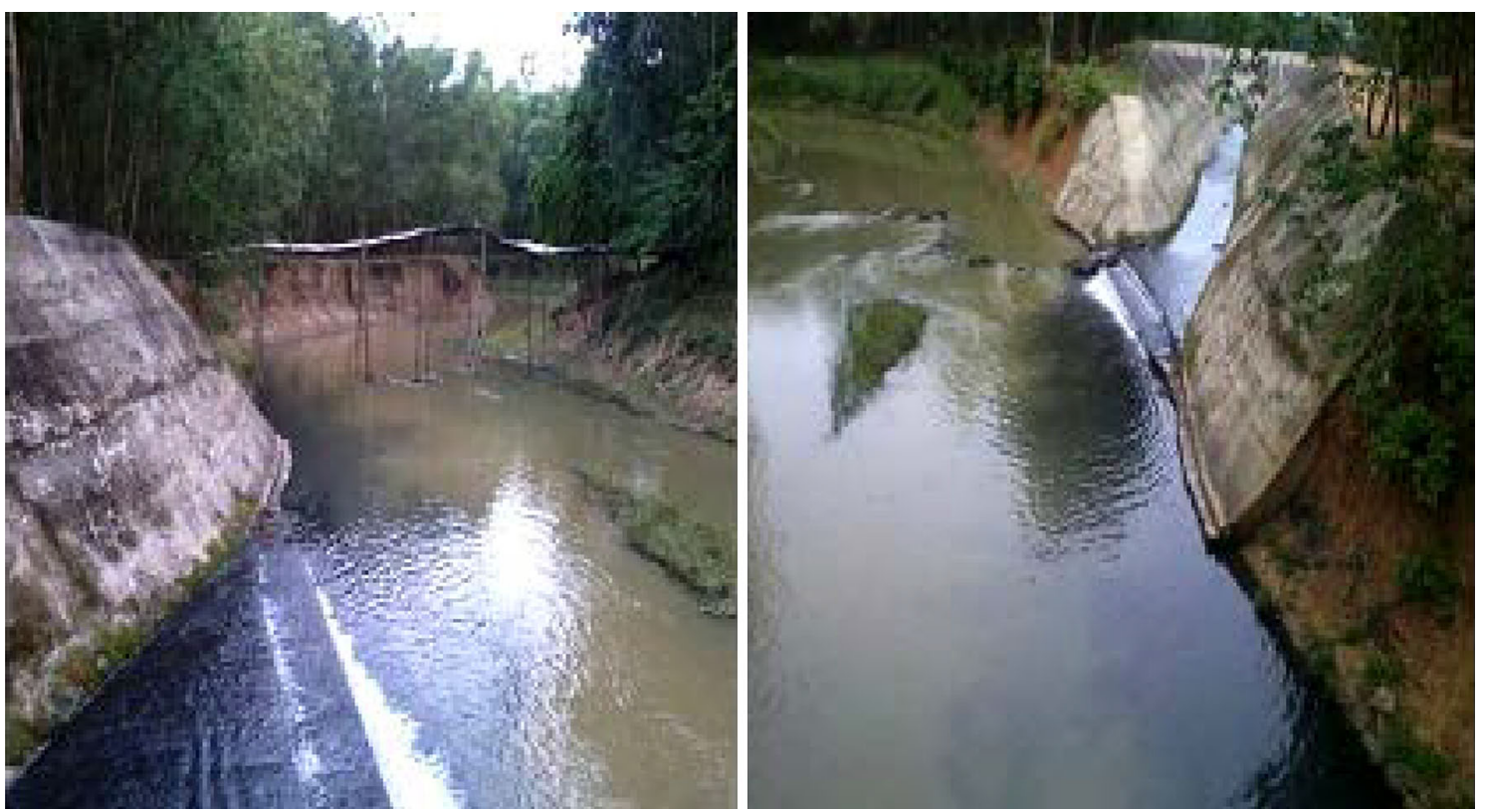

Fig. 11 Polluted blackish water in Tilai river at the connecting point of the discharge channel of power plant

Fig. 12 Beneficial uses of coal fly ash (after ACAA survey 2007; EPRI 2008)

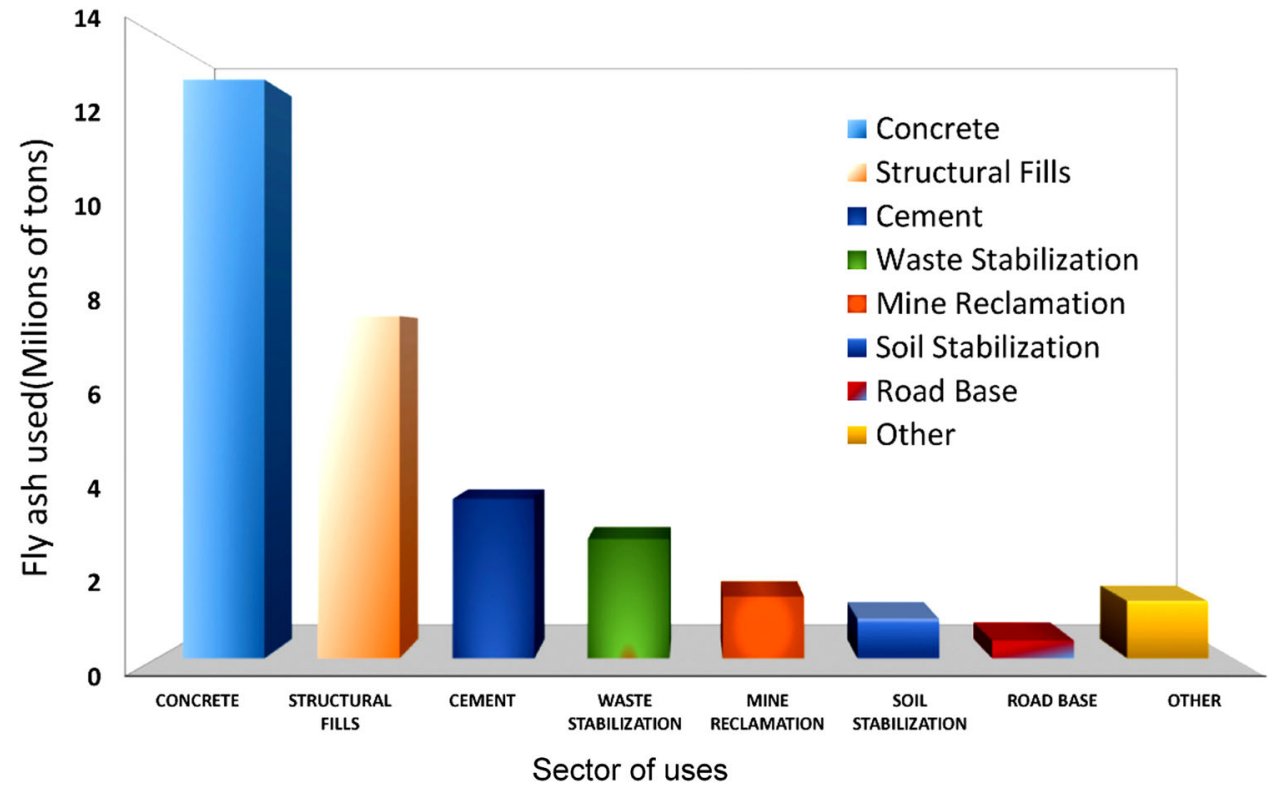

different sectors such as cementing materials, soil improvement and fill materials must be helpful for managing the coal waste of the industry as well the surrounding environment.

\section{Concluding remarks}

The shortage of power is one of the crucial problems in Bangladesh. To solve this problem, it is much indispensable to establish new coal-based power plant for elevating the quantity of electric power in the country. From this point of view, the BTPP was established to meet this energy crisis in the country. However, it should be mentioned here that a considerable amount of fly ash is generating from this plant each year which is simply dumped into two ash ponds as a waste material and not utilizing in anywhere. Thus, considering this situation, the present studies deal principally the assessment of physical, chemical and engineering properties of this ash for its proper utilizations instead of dumping. Finally, based on the results of different analysis, the following conclusions can be drawn: 
1. Physically, the studied ash is a fine powdery material in which color is mostly light gray but ranges from gray to dark gray. The sizes of the particles are fine sand to silty clay-sized glassy spheres composed of predominantly silicon dioxide, aluminum oxide and ferric oxide (more than $90 \%$ ). Thus, the class of the fly ash of this plant is class $\mathrm{F}$.

2. The chemical characteristics and concentrations of all the major and minor parameters of fly ash are in allowable limits where the abundance order of major chemical constituents concentration is $\mathrm{SiO}_{2}>\mathrm{Al}_{2} \mathrm{O}_{3}>\mathrm{TiO}_{2}>$ $\mathrm{Fe}_{2} \mathrm{O}_{3}>\mathrm{CaO}>\mathrm{P}_{2} \mathrm{O}_{5}>\mathrm{MgO}>\mathrm{K}_{2} \mathrm{O}>\mathrm{SO}_{3}>\mathrm{Mn}_{3} \mathrm{O}_{4}>$ $\mathrm{Na}_{2} \mathrm{O}$. Besides, the minor or trace elements concentration order is $\mathrm{Mn}>\mathrm{Zn}>\mathrm{As}>\mathrm{Cu}>\mathrm{Cr}>\mathrm{Pb}>\mathrm{Co}>$ $\mathrm{Cd}$. In fact, the characteristics and concentrations of coal fly ash are thoroughly dependent on the type of source coal with their respective combustion process. In this case, it is very much important to monitor the parametric analysis time to time for identifying its higher concentrations becoming toxic level before utilization.

3. From the particle size analysis, fly ash is a well-graded fine-grained sand silty materials where particles size of this ash is in the range between $<0.075$ and $0.16 \mathrm{~mm}$ in diameter. As a result, the hydraulic conductivity of fly ash is lesser than sand. The hydraulic conductivity of compacted ash mixtures decreased slightly because of increasing resistance to flow of water through pores between particles. The average hydraulic conductivity is $1.43 \times 10^{-3} \mathrm{~cm} / \mathrm{s}$ which corresponds to that of a fine sand/silt mixture or silt. The consistency analysis of fly ash exhibits that the ash is higher consistent than cement.

4. The compaction and compressive strength of fly ash in mixture with cement and sand increases with increasing curing time and cement content. Moreover, the compaction compressive strength properties of fly ash mixtures varied with mixture ratios. The shear strength of fly ash is greater than sand on account of its pozzolanic action. In this analysis the cohesion increases 48-98.67 $\mathrm{kPa}$ with increasing fly ash, whereas the friction angle decreases from $24.67^{\circ}$ to $21.70^{\circ}$.

5. The analyzed physical, chemical and engineering properties of coal ash implied that it can be utilized for numerous functions in construction and geotechnical sectors. The primary use for fly ash is as a direct replacement for Portland cement in concrete, while it can significantly improve the concrete strength qualities. In addition to concrete, ash is used for structural fills, waste stabilization, back fill materials for underground coal mine and so on. Moreover, the fly ash may possibly be employed as an alternative of sand in the construction works. Furthermore, the use of fly ash in soil can enhance the strength and stability of soil for foundation work. Other benefits of using ash include conservation of virgin materials, such as limestone used in cement production consequently reduced the need for disposal sites.

Finally, combining and comparing all of the analyzed results of this analysis, it can be concluded that the fly ash produced from BTPP is an ideal additive raw material for different uses in the construction sectors in the country. Thus, from the environmental safety point of view, this research recommends for properly utilizing this ash in the respective sectors which would be more profitable, safe and sustainable opportunity to reduce the environmental pollution around the power plant area instead of dumping it as a waste materials.

Acknowledgments Firstly, the authors are very thankful to Professor Dr. Bin Chen, Editor-in-Chief, for his kind co-operation regarding the encouraging review processes, advice and publication of the research. Secondly, they are cordially thankful to the anonymous reviewers for their critical evaluation and final suggestion to publish this research. The authors would like to thank to the Ministry of Science and Technology and Ministry of Planning, Bangladesh, for the financial support for the successful completion of a part of the research work; otherwise, it was completely beyond our reach.

\section{References}

Abernethy RF et al (1969) Major ash constituents in U.S. coals. Report of Investigation 7240, Bureau of Mines

ACAA (American Coal Ash Association) (2007) Coal combustion product $(\mathrm{CCP})$ production and use survey results report. http:// www.acaa-usa.org/

ACAA (American Coal Ash Association) (2014) Coal combustion product $(\mathrm{CCP})$ production and use survey results report. http:// www.acaa-usa.org/

Adriano DC et al (1980) Utilization and disposal of fly ash and other coal residues in terrestrial ecosystems: a review. J Environ Qual 9(3):333

Ahmed I (1991) Final report: synthesis study—use of waste materials in highway construction, Purdue University, Indiana Department of Transportation, NTIS, PB91-227736

Alp H, Heveci YH, Sungun AO et al (2009) Pozzolanic characteristics of a natural raw material for use in blended cements. J Sci Technol Trans B Eng 33(B-4):291-300

ASTM C 109 (2010) Compression testing 2-Inch concrete cubes. Five star products, Inc. Corporate Headquarters 750 Commerce Drive Fairfield, CT 06825 USA, p 2

ASTM C 136 (2005) Standard test method for sieve analysis of fine and coarse aggregates, Construction materials testing application. Gaithersburg, MD 20899-2140, p 1-10

ASTM D 5321 (2003) Standard test method for determining the coefficient of soil and geosynthetic or geosynthetic and geosynthetic friction by the direct shear method. ASTM D 5321, Annual book of ASTM standards, Vol 4.09, West Conshohocken, $\mathrm{Pa}$

BPDB (Bangladesh Power Development Board) (2012) Annual report of Bangladesh Power Development Board (unpublished report)

Chang A, Lund L, Page A, Warneke J (1977) Physical properties of fly ash amended soils. J Environ Qual 6(3):267 
Cheremisinoff P (1988) Coal fly ash: power plant waste or byproduct. Power Eng 92(7):40

Chu P, Rafferty M, Delfino T, Gitschlag R (1991) Comparison of Fixation techniques for soil containing arsenic. In: Emerging technologies in hazardous waste management II symposium, New Jersey, Environmental Index: 91-06991

CMC (2003) Preliminary geology and exploration report of Barapukuria Coal Mine, Bangladesh

Collins R (1988) A comparison between coal ash and incinerator ash. In: Proceedings of the 1st international conference on municipal solid waste combustor ash utilization, Philadelphia, pp 99-108

Cutruneo CMNL, Oliveira MLS, Ward CR, Hower JC, de Brum IAS, Sampaio CH, Kautzmann RM, Taffarel SR, Teixeira EC, Silva LFO (2014) A mineralogical and geochemical study of three Brazilian coal cleaning rejects: demonstration of electron beam applications. Int J Coal Geol 130:33-52

Diamond S (1985) Selection and use of fly ash for highway concrete final report. Purdue University, Indiana, Report No. FHWA/IN/ JHRP-85/8

Dias CL, Oliveira MLS, Hower JC, Taffarel SR, Kautzmann RM, Silva LFO (2014) Nanominerals and ultrafine particles from coal fires from Santa Catarina, South Brazil. Int J Coal Geol 122:50-60

El-Mogazi E, Lisk D, Weinstein L (1988) A review of physical, chemical, and biological properties of fly ash and effects on agricultural ecosystems. Sci Total Environ 74:1

EPRI (Electric Power Research Institute) (2008) Electric utility traces substances synthesis report. Electric Power Research Institute, Palo Alto, California Palo Alto, CA, 1015545

Ferguson G, Levorson SM (1999) Soil and pavement base stabilization with self cementing coal fly ash. American Coal Ash Association International, Alexandria

Finkelman RB, Palmer CA, Krasnow MR (1990) Combustion and leaching behavior of elements in the Argonne premium coal samples. Energy Fuel 4:755-766

Garcia KO, Teixeira EC, Agudelo-Castaneda DM, Braga M, Alabarse PG, Kronbauer MA, Izquierd M, Dai S, Waanders FB, Wagner NJ, Mastalerz M, Hower JC, Oliveira MLS, Taffarel SR, Bizani D, Silva LFO (2013) Geochemistry of ultra-fine and nanocompounds in coal gasification ashes: a synoptic view. Sci Total Environ 456-457:95-103

Goodwin R (1988) Coal and incinerator ash in pozzolanic applications. In: Eighmy T, Chesner W (eds) Proceedings of the first international conference on Municipal Solid Waste Combustor Ash Utilization, Philadelphia, Pa, pp 109-117

Gutta DC (1999) Environmental aspects of selected trace elements associated with coal and natural waters of Pench Vally coalfield of India and their impact on human health. Int J Coal Geol 40:133-149

Haas C, Macak J (1985) Revegetation using coal ash mixtures. J Environ Eng 111(5):559

Hashan M, Howladar MF, Jahan LN, Deb PK (2013) Ash content and its relevance with the coal grade and environment in Bangladesh. Int J Sci Eng Res 4(4):669-676

Howladar MF (2012) Coal mining impacts on water environs around the Barapukuria coal mining area, Dinajpur, Bangladesh. J Environ Earth Sci. doi:10.1007/s12665-012-2117-x

Howladar MF (2015) Assessment of chemical characteristics of surface water environment with its possible pollution sources around the Barapukuria Thermal Power Plant Impacted area, Dinajpur, Bangladesh (submitted research for publication)

Howladar MF, Hasan K (2014) A study on the development of subsidence due to the extraction of 1203 slice with its associated factors around Barapukuria underground coal mining industrial area, Dinajpur, Bangladesh. Environ Earth Sci 72(9):3699-3713. doi:10.1007/s12665-014-3419-y

Howladar MF, Karim MM (2014) The selection of backfill materials for Barapukuria Underground Coal Mine, Dinajpur, Bangladesh: insight from the assessments of engineering properties of some selective materials. Environ Earth Sci. doi:10.1007/s12665-014-3419-y

Howladar MF, Deb PK, Muzemder ATMSH, Ahmed M (2014) Evaluation of water resources around Barapukuria Coal Mine industrial area, Dinajpur, Bangladesh. Appl Water Sci. doi:10. 1007/s13201-014-0207-5

Howladar MF, Islam MT, Deb PK, Karim M, Mia MI et al (2015) An analysis of soil quality for environment around the Barapukuria Coal Fired Thermal Power Plant, Parbatipur, Dinajpur, Bangladesh. Earth Resour 3:1-6. doi:10.12966/ne.05.01.2015

IS (Indian Standard) 4031 (1988) Methods of physical tests for hydraulic cement (part 4) determination of consistency of standard cement paste

Karim MA (1997) Building highway embankments of fly/bottom ash mixtures. Joint Highway Research Project, Final Report, FHWA/ IN/JTRP-97/1, Purdue University, W. Lafayette, Indiana

Karim MM, Howladar MF (2013) Volumetric estimation of coal resources in seam VI for require backfill materials of Barapukuria coal mine, Dinajpur, Bangladesh. J Earth Sci 2(6):113-119. doi:10.11648/j.earth.20130206.11

Karim MM, Howladar MF, Shine FMM (2014) A study on the preliminary cost estimation for hydraulic backfill process in Barapukuria coal mine, Dinajpur, Bangladesh. J Eng Geol Hydrogeol 2(3):37-45. doi:10.12966/jegh.08.02.2014

Manz OE (1999) Coal fly ash: a retrospective and future look. J Fuel 78(2):133-136

Martin J, Collins R, Browning J, Biehl F (1990) Properties and use of fly ashes for embankments. J Energy Eng 116(2):71

Martinello K, Oliveira MLS, Molossi FA, Ramos CG, Teixeira EC, Kautzmann RM, Oliveira MLS, Ward CR (2014) Direct identification of hazardous elements in ultra-fine and nanominerals from coal fly ash produced during diesel co-firing. Sci Total Environ 470-471:444-452

Nath S (1997) Constraints in the utilization of fly ash. Indian J Environ Prot 17(2):103-106

Neville AM (1995) Properties of concrete. Prentice Hall, London

Openshaw SC (1992) Utilization of coal ash. An unpublished graduate reports. Departments of environmental engineering and civil engineering, University of Florida, p 53

Rodriguez AK, Castillo H, Sowers GF (1988) Soil mechanics in highway engineering. Trans Tech Publications, Clausthal-Zellerfeld

Roy WR, Griffin RA, Dickerson DR, Schuller RM (1984) Illinois basin coal fly ashes: chemical characterization and solubility. J Environ Sci Technol 18:734-745

Sanchís J, Oliveira LFS, De Leão FB, Farrè M, Barcelò D (2015) Liquid chromatography-atmospheric pressure photoionizationOrbitrap analysis of fullerene aggregates on surface soils and river sediments from Santa Catarina (Brazil). Sci Total Environ 505:172-179

Sandhu S, Mills G (1991) Mechanisms of mobilization and attenuate of inorganic contaminants in coal ash basins. ACS Emerging Technologies in Hazardous Waste Management II, New Jersey, Environmental Index:91-07328

Selvig WA, Gibson FH (1956) Analysis of ash from United States coals, Bulletin 567, Bureau of Mines

Silva LFO, Moreno T, Querol X (2009) An introductory TEM study of Fe-nanominerals within coal fly ash. Sci Total Environ 407:4972-4974

Theis T, Gardner K (1990) Environmental assessment of ash disposal. Crit Rev Environ Control 20(1):21

Torrey S (1978) Coal ash utilization: fly ash, bottom ash and slag. Torrey S Ed., New Jersey: Noyes Data Corporation

Turgeon R (1988) Fly ash fills valley. Civ Eng ASCE 58:67

Usmen M, Bowders J, Gidley J (1988) Low permeability liners incorporating fly ash. Proc ASCE National Convention, New York, pp 50-65 
Wang Y, Ren D, Zhao F (1999) Comparative leaching experiments for trace elements in raw coal, laboratory ash, fly ash and bottom ash. Int J Coal Geol 40:103-108

Wardell A (1991) Techno-economic feasibility study, Barapukuria Coal project, Dinajpur, Bangladesh. vol. 1 \& 2, Chap. 1 \& 2

Wong M, Wong J (1989) Germination and seedling growth of vegetable crops in fly ash-amended soils, agriculture. Ecosyst Environ 26:23
Yoshimoto N, Hyodo M, Nakata Y, Orense R, Hongo T, Ohnaka A (2012) Evaluation of shear strength and mechanical properties of granulated coal ash based on single particle strength. Soils Found 52(2):321-334 